\title{
Crystal design approaches for the synthesis of paracetamol co-crystals
}

Article

Accepted Version

Srirambhatla, V. K., Kraft, A., Watt, S. and Powell, A. V. (2012)

Crystal design approaches for the synthesis of paracetamol co-crystals. Crystal Growth \& Design, 12 (10). pp. 4870-4879. ISSN 1528-7483 doi: https://doi.org/10.1021/cg300689m Available at https://centaur.reading.ac.uk/34128/

It is advisable to refer to the publisher's version if you intend to cite from the work. See Guidance on citing.

To link to this article DOI: http://dx.doi.org/10.1021/cg300689m

Publisher: American Chemical Society

All outputs in CentAUR are protected by Intellectual Property Rights law, including copyright law. Copyright and IPR is retained by the creators or other copyright holders. Terms and conditions for use of this material are defined in the End User Agreement.

\section{www.reading.ac.uk/centaur}

\section{CentAUR}

Central Archive at the University of Reading

Reading's research outputs online 


\title{
Crystal Design Approaches for the Synthesis of Paracetamol Co- Crystals
}

\author{
Vijay K. Srirambhatla, ${ }^{\dagger}$ Arno Kraft, ${ }^{\dagger}$ Stephen Watt, $^{\ddagger}$ and Anthony V. Powell ${ }^{*}{ }^{\dagger}$ \\ ${ }^{\dagger}$ Department of Chemistry, School of Engineering and Physical Sciences, Heriot-Watt University, Edinburgh EH14 4AS, U.K. \\ ${ }^{\ddagger}$ Solid Form Solutions Ltd, The Fleming Building, Edinburgh Technopole, Milton Bridge, Penicuik, EH26 0BE, U.K.
}

Supporting Information

ABSTRACT: Crystal engineering principles were used to design three new co-crystals of paracetamol. A variety of potential cocrystal formers were initially identified from a search of the Cambridge Structural Database for molecules with complementary hydrogen-bond forming functionalities. Subsequent screening by powder X-ray diffraction of the products of the reaction of this library of molecules with paracetamol led to the discovery of new binary crystalline phases of paracetamol with trans-1,4-

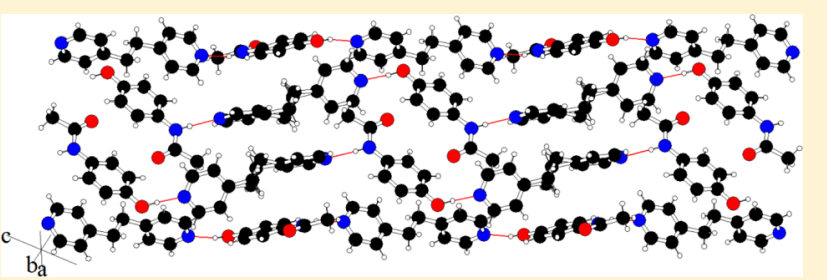
diaminocyclohexane (1); trans-1,4-di(4-pyridyl)ethylene (2); and 1,2-bis(4-pyridyl)ethane (3). The co-crystals were characterized by IR spectroscopy, differential scanning calorimetry, and ${ }^{1} \mathrm{H}$ NMR spectroscopy. Single crystal X-ray structure analysis reveals that in all three co-crystals the co-crystal formers (CCF) are hydrogen bonded to the paracetamol molecules through $\mathrm{O}-\mathrm{H} \cdots \mathrm{N}$ interactions. In co-crystals (1) and (2) the CCFs are interleaved between the chains of paracetamol molecules, while in co-crystal (3) there is an additional $\mathrm{N}-\mathrm{H} \cdots \mathrm{N}$ hydrogen bond between the two components. A hierarchy of hydrogen bond formation is observed in which the best donor in the system, the phenolic $\mathrm{O}-\mathrm{H}$ group of paracetamol, is preferentially hydrogen bonded to the best acceptor, the basic nitrogen atom of the co-crystal former. The geometric aspects of the hydrogen bonds in co-crystals 1-3 are discussed in terms of their electrostatic and charge-transfer components.

\section{INTRODUCTION}

Co-crystals, or multicomponent molecular crystals, ${ }^{1}$ include addition compounds, ${ }^{2}$ organic molecular complexes, ${ }^{3}$ and solidstate complexes. ${ }^{4}$ The definition of a co-crystal is a subject of debate. ${ }^{1,5,6}$ While there is no consensus over the precise definition of what constitutes a co-crystal, a broad generality is that that they are crystalline materials comprising at least two different molecular components. Pharmaceutical co-crystals represent a subset of this broad class, in which at least one of the components is an active pharmaceutical ingredient (API). It is well established that different forms of a given pharmaceutically active compound may have different physical properties, ${ }^{7}$ salt formation being one of the common approaches to modifying the physical properties of a drug. However, salt formation is feasible only when the API possesses a suitable ionizable site. In contrast, co-crystal formation exploits the very features that lead to a compound being an API: the presence of functional groups. Moreover the functional groups may allow APIs to exhibit polymorphism, ${ }^{8}$ exist as solvates, ${ }^{9}$ or form cocrystals. ${ }^{10}$ Given the importance of APIs, it is perhaps surprising that only in recent years have crystal engineering concepts been applied to APIs ${ }^{11-15}$ to enhance the range of potentially usable forms of a given drug substance.

Crystal engineering can be defined as the rational design of functional molecular solids. ${ }^{16}$ The concept was introduced by Pepinsky ${ }^{17}$ and applied by Schmidt ${ }^{18}$ to organic solid-state photochemical reactions. Thomas et al. ${ }^{19}$ in reviewing the reactivity of this category of reaction noted that the reactivity in the solid state is governed by the precise control of molecular orientation and stacking sequences in the crystal structures. This observation paved the way for the further design and synthesis of new solids based on crystal engineering strategies. The basic understanding of crystal engineering concepts is based on analysis of the manner in which molecules are packed in molecular crystals also considered as supermolecules. ${ }^{20}$ The crystal structure of any organic compound may be considered to be the result of a series of competing, directional, and predictable interactions between functional groups, giving rise to recognizable structural building units termed supramolecular synthons. ${ }^{21}$ Identifying reliable and robust supramolecular synthons is key for effective crystal engineering. Shattock et al. $^{22}$ have demonstrated that database mining using the Cambridge Structural Database (CSD) provides valuable information on the occurrence of a particular supramolecular synthon in series of closely related structures, which may be applied to the synthesis of a wide range of co-crystals. The total number of reported co-crystal structures in the CSD remains relatively low (8552 entries, ca. 3.3\% of all organic entries) in comparison to the total number of organic structures $(254475$ entries). ${ }^{23}$ Database mining has been shown to be an effective approach to the search for hydrogen-bonded synthons for the construction of organic crystal structures. ${ }^{24}$

Received: May 20, 2012

Revised: August 30, 2012 
Paracetamol or acetaminophenol is a widely used analgesic and antipyretic drug that is commonly used for the relief of fever, headaches, and other minor aches and pains. It belongs to a class of drugs known as aniline analgesics. In its crystalline state paracetamol commonly exists in two polymorphic forms. ${ }^{25}$ The monoclinic form I (Figure 1a,b) is considered

(a)

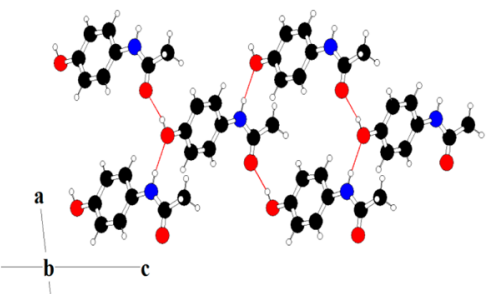

(b)

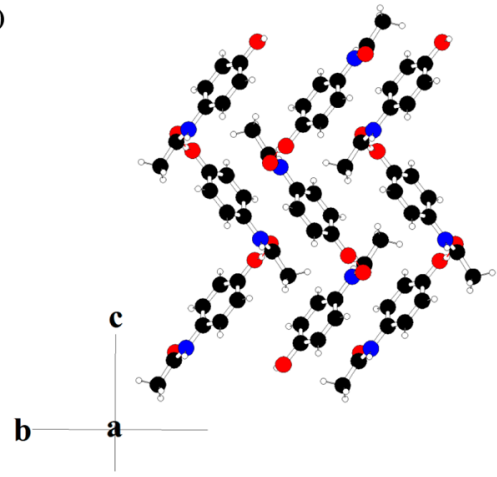

(c)

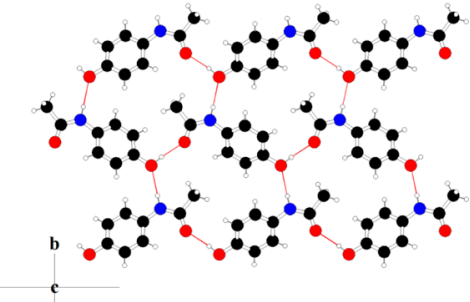

Figure 1. The packing arrangement of form I of paracetamol viewed along (a) [010] and (b) [100] and (c) form II viewed along [001]. Solid red lines represent intermolecular hydrogen bonds. Key: nitrogen, blue circles; oxygen, red circles; carbon, black circles; hydrogen, small white circles.

to be the thermodynamically stable form. Form II which crystallizes in the orthorhombic system (Figure 1c) is of interest in formulations because of its superior compression properties compared to that of form I. Although a third polymorph (form III) has been identified, ${ }^{26}$ until recently its crystal structure ${ }^{27}$ remained elusive. The paracetamol molecule consists of a benzene ring substituted with hydroxyl and acetamide groups in the para $(1,4)$ positions. Both of the structurally characterized forms of paracetamol exhibit a similar pattern of hydrogen bonds involving the phenolic $\mathrm{O}-\mathrm{H}$ group, which acts an acceptor in $\mathrm{N}-\mathrm{H} \cdots \mathrm{O}$ interactions and as a donor in $\mathrm{O}-\mathrm{H} \cdots \mathrm{O}=\mathrm{C}$ interactions, to generate in both forms I and II, a two-dimensional network. Using the graph set approach to hydrogen bonding of Bernstein et al. ${ }^{28}$ both forms I and II may be described as having $C(7)$ and $C(9)$ motifs. However, the two polymorphs of paracetamol differ in the orientation of the molecules. In form I paracetamol molecules are arranged in a herringbone pattern to form puckered hydrogen-bonded sheets, whereas in form II, they form flat hydrogen-bonded sheets.

In addition to the reported polymorphic forms, a number of research groups have synthesized and characterized several cocrystal/solvate forms of paracetamol. Karki et al. ${ }^{29}$ synthesized four co-crystals of paracetamol involving theophylline, oxalic acid, naphthalene, and phenazine as CCFs. They also demonstrated that the co-crystal forms possess better compression properties compared to that of form II. In addition to these pharmaceutically acceptable co-crystals, multicomponent crystalline forms (both two-component co-crystals and solvates) of paracetamol containing $N, N$-dimethylpiperazine, 4,4'-bipyridine, $N$-methylmorpholine, morpholine, 1,4,8,11-tetraazacyclotetradecane, 1,4-diazabicyclo[2.2.2]octane, ethanol, water, piperazine, and 1,4-dioxane as CCFs or solvate have been reported. ${ }^{30}$ In all the reported multicomponent crystals of paracetamol the hydrogen bonds involving the donor groups, i.e., the phenolic $\mathrm{O}-\mathrm{H}$ and the amidic $\mathrm{N}-\mathrm{H}$ participate in conventional hydrogen bonds through $\mathrm{O}-\mathrm{H} \cdots \mathrm{N} / \mathrm{O}$ and $\mathrm{N}-\mathrm{H} \cdots \mathrm{O} / \mathrm{N}$ interactions involving acceptors from either the paracetamol molecules or CCFs. Similarly the acceptor groups are involved in $\mathrm{O} \cdots \mathrm{H}-\mathrm{O} / \mathrm{N}$ type intermolecular interactions.

If we consider form $\mathrm{I}$, the strongest hydrogen bonds are formed between the phenolic $\mathrm{O}-\mathrm{H}$ donor and the amide oxygen acceptor $(d(\mathrm{H} \cdots \mathrm{O})=1.77 \AA)$, while those between the $\mathrm{N}-\mathrm{H}$ donor and $\mathrm{O}-\mathrm{H}$ acceptor are weaker $(d(\mathrm{H} \cdots \mathrm{O})=2.00$ $\AA)$. Therefore, in order to make co-crystals of paracetamol, it is necessary to break these hydrogen bonds and introduce interactions with the CCF that are of comparable strength. In seeking to identify suitable co-crystal formers (CCFs) to promote such interactions, we performed a search of the Cambridge Structural Database (CSD) for molecules containing functional groups that form hydrogen bonds with similar geometrical parameters. The results of this targeted search suggested a series of molecules in which these functional groups are present. These molecules were then screened for co-crystal formation. This led ultimately to the synthesis of the three new co-crystals of paracetamol with trans-1,4-diaminocyclohexane, 1,2-bis(4-pyridyl)ethane, and trans-1,4-di(4-pyridyl)ethylene (Figure 2) reported here.

\section{EXPERIMENTAL SECTION}

CSD Analysis. Identification of candidate co-crystal formers suitable for paracetamol was achieved by carrying out an analysis of structural information contained in the Cambridge Structural Database<smiles>CC(=O)Nc1ccc(O)cc1</smiles>

paracetamol<smiles>C(=C/c1ccncc1)\c1ccncc1</smiles>

trans-1,4-di(4-pyridyl)ethylene
$\mathrm{H}_{2} \mathrm{~N} \mathrm{NH}_{2}$

trans-1,4-diaminocyclohexane

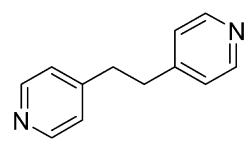

1,2-bis(4-pyridyl)ethane
Figure 2. Chemical structures of the active pharmaceutical ingredient and cocrystal formers investigated in this work. 
Table 1. The Potential Co-Crystal Formers Used for Screening with Paracetamol

\begin{tabular}{|c|c|c|c|}
\hline $\begin{array}{l}\text { Potential co-crystal } \\
\text { former }\end{array}$ & $\begin{array}{c}\text { Functional group } \\
\text { targeted }\end{array}$ & Solvents investigated & Observations \\
\hline Bipyridyl & pyridyl nitrogen & $\begin{array}{c}\mathrm{CH}_{3} \mathrm{OH}, \mathrm{EtOH}, \mathrm{ACN}, \mathrm{CHCl}_{3}, \\
\mathrm{CH}_{3} \mathrm{COCH} \text {, THF, and } n- \\
\text { propanol. }\end{array}$ & $\begin{array}{l}\text { Co-crystal as reported } \\
\text { in Ref. } 23(\mathrm{~b})\end{array}$ \\
\hline Piperazine & amine & $\begin{array}{c}\mathrm{CH}_{3} \mathrm{OH}, \mathrm{EtOH}, \mathrm{ACN}, \mathrm{CHCl}_{3}, \\
\mathrm{CH}_{3} \mathrm{COCH}_{3} \text {, THF, and } n- \\
\text { propanol. }\end{array}$ & $\begin{array}{l}\text { Co-crystal as reported } \\
\text { in Ref. } 23(\mathrm{~b})\end{array}$ \\
\hline pyrazine & pyridyl nitrogen & $\begin{array}{c}\mathrm{CH}_{3} \mathrm{OH}, \mathrm{EtOH}, \mathrm{ACN}, \mathrm{CHCl}_{3}, \\
\mathrm{CH}_{3} \mathrm{COCH} \text {, THF, and } n^{-} \\
\text {propanol. }\end{array}$ & $\begin{array}{l}\text { PXRD patterns exhibit } \\
\text { reflections from } \\
\text { paracetamol only }\end{array}$ \\
\hline $\begin{array}{l}\text { 4,4'-trimethylene } \\
\text { dipyridine }\end{array}$ & Pyridyl nitrogen & $\begin{array}{c}\mathrm{CH}_{3} \mathrm{OH}, \mathrm{EtOH}, \mathrm{ACN}, \mathrm{CHCl}_{3}, \\
\mathrm{CH}_{3} \mathrm{COCH}_{3}, \mathrm{THF} \text {, and } n- \\
\text { propanol. }\end{array}$ & $\begin{array}{l}\text { Sticky material unable } \\
\text { to analyse by PXRD }\end{array}$ \\
\hline imidazole & imidazole & $\begin{array}{c}\mathrm{CH}_{3} \mathrm{OH}, \mathrm{EtOH}, \mathrm{ACN}, \mathrm{CHCl}_{3}, \\
\mathrm{CH}_{3} \mathrm{COCH}_{3}, \mathrm{THF} \text {, and } n- \\
\text { propanol. }\end{array}$ & \multirow{17}{*}{$\begin{array}{l}\text { PXRD patterns exhibit } \\
\text { reflections from } \\
\text { starting components } \\
\text { indicating a physical } \\
\text { mixture }\end{array}$} \\
\hline caffeine & pyridyl nitrogen & $\begin{array}{c}\mathrm{CH}_{3} \mathrm{OH}, \mathrm{EtOH}, \mathrm{ACN}, \mathrm{CHCl}_{3}, \\
\mathrm{CH}_{3} \mathrm{COCH}_{3} \text {, THF, and } n^{-} \\
\text {propanol. }\end{array}$ & \\
\hline nicotinamide & $\begin{array}{l}\text { amide, pyridyl } \\
\text { nitrogen }\end{array}$ & $\begin{array}{c}\mathrm{CH}_{3} \mathrm{OH}, \mathrm{EtOH}, \mathrm{ACN}, \mathrm{CHCl}_{3}, \\
\mathrm{CH}_{3} \mathrm{COCH}_{3} \text {, THF, and } n- \\
\text { propanol. }\end{array}$ & \\
\hline succinic acid & carboxylic acid & $\begin{array}{c}\mathrm{CH}_{3} \mathrm{OH}, \mathrm{EtOH}, \mathrm{ACN}, \mathrm{CHCl}_{3}, \\
\mathrm{CH}_{3} \mathrm{COCH}_{3}, \mathrm{THF} \text {, and } n- \\
\text { propanol. }\end{array}$ & \\
\hline fumaric acid & carboxylic acid & $\begin{array}{c}\mathrm{CH}_{3} \mathrm{OH}, \mathrm{EtOH}, \mathrm{ACN}, \mathrm{CHCl}_{3}, \\
\mathrm{CH}_{3} \mathrm{COCH} \text {, THF, and } n- \\
\text { propanol. }\end{array}$ & \\
\hline malonic acid & carboxylic acid & $\begin{array}{c}\mathrm{CH}_{3} \mathrm{OH}, \mathrm{EtOH}, \mathrm{ACN}, \mathrm{CHCl}_{3}, \\
\mathrm{CH}_{3} \mathrm{COCH}_{3} \text {, THF, and } n- \\
\text { propanol. }\end{array}$ & \\
\hline adipic acid & carboxylic acid & $\begin{array}{c}\mathrm{CH}_{3} \mathrm{OH}, \mathrm{EtOH}, \mathrm{ACN}, \mathrm{CHCl}_{3}, \\
\mathrm{CH}_{3} \mathrm{COCH}_{3}, \mathrm{THF} \text {, and } n- \\
\text { propanol. }\end{array}$ & \\
\hline maleic acid & carboxylic acid & $\begin{array}{c}\mathrm{CH}_{3} \mathrm{OH}, \mathrm{EtOH}, \mathrm{ACN}, \mathrm{CHCl}_{3}, \\
\mathrm{CH}_{3} \mathrm{COCH} \text {, THF, and } n- \\
\text { propanol. }\end{array}$ & \\
\hline malic acid & carboxylic acid & $\begin{array}{c}\mathrm{CH}_{3} \mathrm{OH}, \mathrm{EtOH}, \mathrm{ACN}, \mathrm{CHCl}_{3}, \\
\mathrm{CH}_{3} \mathrm{COCH}_{3} \text {, THF, and } n- \\
\text { propanol. }\end{array}$ & \\
\hline 1-naphthol & hydroxyl group & $\begin{array}{c}\mathrm{CH}_{3} \mathrm{OH}, \mathrm{EtOH}, \mathrm{ACN}, \mathrm{CHCl}_{3}, \\
\mathrm{CH}_{3} \mathrm{COCH} \text {, THF, and } n- \\
\text { propanol. }\end{array}$ & \\
\hline resorcinol & hydroxyl group & $\begin{array}{c}\mathrm{CH}_{3} \mathrm{OH}, \mathrm{EtOH}, \mathrm{ACN}, \mathrm{CHCl}_{3}, \\
\mathrm{CH}_{3} \mathrm{COCH} \text {, THF, and } n- \\
\text { propanol. }\end{array}$ & \\
\hline melamine & $\begin{array}{l}\text { 1,3,5-triazine, } \\
\text { amine }\end{array}$ & $\begin{array}{c}\mathrm{CH}_{3} \mathrm{OH}, \mathrm{EtOH}, \mathrm{ACN}, \mathrm{CHCl}_{3}, \\
\mathrm{CH}_{3} \mathrm{COCH} \text {, THF, and } n- \\
\text { propanol. }\end{array}$ & \\
\hline benzoic acid & carboxylic acid & $\begin{array}{c}\mathrm{CH}_{3} \mathrm{OH}, \mathrm{EtOH}, \mathrm{ACN}, \mathrm{CHCl}_{3}, \\
\mathrm{CH}_{3} \mathrm{COCH} \text {, THF, and } n- \\
\text { propanol. }\end{array}$ & \\
\hline $\begin{array}{l}\text { 2,5-dihydroxy } \\
\text { benzoic acid }\end{array}$ & $\begin{array}{l}\text { carboxylic acid, } \\
\text { hydroxyl group }\end{array}$ & $\begin{array}{c}\mathrm{CH}_{3} \mathrm{OH}, \mathrm{EtOH}, \mathrm{ACN}, \mathrm{CHCl}_{3}, \\
\mathrm{CH}_{3} \mathrm{COCH} \text {, THF, and } n- \\
\text { propanol. }\end{array}$ & \\
\hline isonicotinamide & $\begin{array}{l}\text { pyridyl nitrogen, } \\
\text { amide }\end{array}$ & $\begin{array}{c}\mathrm{CH}_{3} \mathrm{OH}, \mathrm{EtOH}, \mathrm{ACN}, \mathrm{CHCl}_{3}, \\
\mathrm{CH}_{3} \mathrm{COCH}_{3} \text {, THF, and } n- \\
\text { propanol. }\end{array}$ & \\
\hline 3-isochromanone & Carbonyl group & $\begin{array}{c}\mathrm{CH}_{3} \mathrm{OH}, \mathrm{EtOH}, \mathrm{ACN}, \mathrm{CHCl}_{3}, \\
\mathrm{CH}_{3} \mathrm{COCH}_{3} \text {, THF, and } n- \\
\text { propanol. }\end{array}$ & \\
\hline $\begin{array}{c}\text { (3S)-cis-3,6- } \\
\text { dimethyl-1,4- } \\
\text { dioxane-2,5-dione }\end{array}$ & Carbonyl group & $\begin{array}{c}\mathrm{CH}_{3} \mathrm{OH}, \mathrm{EtOH}, \mathrm{ACN}, \mathrm{CHCl}_{3} \text {, } \\
\mathrm{CH}_{3} \mathrm{COCH}_{3} \text {, THF, and } n- \\
\text { propanol. }\end{array}$ & \\
\hline
\end{tabular}


Table 1. continued

\begin{tabular}{|c|c|c|c|}
\hline $\begin{array}{c}\text { trans-1,4- } \\
\text { diaminocycloheane }\end{array}$ & Amine & $\begin{array}{c}\mathrm{CH}_{3} \mathrm{OH}, \mathrm{EtOH}, \mathrm{ACN}, \mathrm{CHCl}_{3}, \\
\mathrm{CH}_{3} \mathrm{COCH}_{3}, \mathrm{THF}, \text { and } n- \\
\text { propanol. }\end{array}$ & $\begin{array}{c}\text { With each solvent the } \\
\text { same PXRD pattern } \\
\text { results that is different } \\
\text { from that of either of } \\
\text { the starting materials }\end{array}$ \\
\hline $\begin{array}{c}\text { trans-1,4-di(4- } \\
\text { pyridyl)ethylene }\end{array}$ & Pyridyl nitrogen & $\begin{array}{c}\text { The solid product from } \\
\text { each grinding } \\
\text { experiment produces a } \\
\text { different PXRD } \\
\mathrm{CH}_{3} \mathrm{OH}, \mathrm{EtOH}, \mathrm{ACN}, \mathrm{CHCl}_{3}, \\
\mathrm{CH}_{3} \mathrm{COCH}, \mathrm{THF}, \text { and } n- \\
\text { propanol. } \\
\text { pattern, each of which } \\
\text { differs from that of } \\
\text { either of the starting } \\
\text { materials }\end{array}$ \\
\hline $\begin{array}{c}\text { 1,2-bis(4- } \\
\text { pyridyl)ethane }\end{array}$ & Pyridyl nitrogen & $\begin{array}{c}\mathrm{CH}_{3} \mathrm{OH}, \mathrm{EtOH}, \mathrm{ACN}, \mathrm{CHCl}, \\
\mathrm{CH}_{3} \mathrm{COCH}, \mathrm{THF}, \text { and } n- \\
\text { propanol. }\end{array}$ & $\begin{array}{c}\text { With each solvent the } \\
\text { same PXRD pattern } \\
\text { results that is different } \\
\text { from that of either of } \\
\text { the starting materials }\end{array}$ \\
\hline
\end{tabular}

(CSD). The search was performed using CSD version 5.33 (November 2011) + 2 updates. The following search criteria were applied: only those organic structures for which three-dimensional structural coordinates have been determined were considered; only those crystal structures for which $R \leq 7.5 \%$ were retained in the results of the search; structures which showed evidence of disorder or had been shown to contain errors were excluded, as were those for polymeric species.

All starting materials were obtained from Sigma-Aldrich and were used as obtained. The solvent-drop grinding method ${ }^{31}$ was used to screen for co-crystal formation. Stoichiometric amounts of paracetamol and potential CCF were ground together with a mortar and pestle for ca. 5 min following addition of solvent ( $15 \mu \mathrm{L}$ of solvent per $50 \mathrm{mg}$ of starting materials). The grinding experiments were performed in seven different solvents, methanol, ethanol, acetonitrile, chloroform, acetone, tetrahydrofuran, and $n$-propanol, representing a wide range of dielectric constants $(4.8-37.5)$ and containing at least one representative from each of the polar protic, polar aprotic, and nonpolar solvent categories. The resulting solid material was analyzed by powder X-ray diffraction (PXRD). A total of 168 liquid assisted grinding experiments were conducted. The CCFs and solvent systems investigated are presented in Table 1 .

Analysis of the X-ray diffraction data of the polycrystalline materials arising from these solvent drop-grinding experiments revealed that for critical paracetamol/CCF ratios, reflections arising from the starting materials are absent, indicating the presence of new phases, when trans-1,4-diaminocyclohexane, 1,2-bis(4-pyridyl)ethane, and 1,2-di(4pyridyl)ethylene are used as CCFs. These molecules were subsequently used to prepare single-crystal samples by solvent evaporation methods, using the ratios for which reflections arising from the starting materials were absent from PXRD data. Crystallization experiments were conducted in various combinations of commonly occurring organic solvents; however, only those experiments which led to diffraction quality crystals are detailed below. Single crystals of paracetamol/trans-1,4-diaminocyclohexane (1) were prepared from a solution of paracetamol $(302 \mathrm{mg}, 2.00$ $\mathrm{mmol})$ and trans-1,4-diaminocyclohexane $(114 \mathrm{mg}, 1.00 \mathrm{mmol})$ in 3 $\mathrm{mL}$ of methanol. The solution was heated for $3 \mathrm{~min}$ before being allowed to stand at room temperature. After 4 days colorless crystals of (1) appeared. Pale yellow colored crystals of paracetamol:1,2-di(4pyridyl)ethylene (2) were obtained by evaporation, over 3 days, of solvent from a solution containing $2 \mathrm{mmol}(302 \mathrm{mg})$ of paracetamol and $1 \mathrm{mmol}$ of 1,2-di(4-pyridyl)ethylene $(182 \mathrm{mg})$ in $5 \mathrm{~mL}$ of methanol. A similar method was used for the preparation of paracetamol/1,2-bis(4-pyridyl)ethane (3) from a 1:1 molar ratio of paracetamol $(151 \mathrm{mg}, 1 \mathrm{mmol}) / 1$,2-bis(4-pyridyl)ethane (184 mg, $1.00 \mathrm{mmol}$ ) in $2 \mathrm{~mL}$ of dimethyl sulphoxide. Crystals emerged after allowing the solution to stand at room temperature for 5 days.

Polycrystalline materials obtained from the crystallization experiments were analyzed by PXRD and compared with powder diffraction patterns generated from the structures determined by single-crystal methods. Diffraction data for the powders resulting from the use of trans-1,4-diaminocyclohexane and 1,2-bis(4-pyridyl)ethane as CCFs are consistent with a bulk phase of co-crystals (1) and (3) respectively, irrespective of the solvent used. In the case where trans-1,4-di(4pyridyl)ethylene was used as a CCF the PXRD pattern matches the simulated powder diffraction pattern generated from the single crystal structure of (2) when the solvent of crystallization is methanol. However, the powder diffraction data for products of crystallization experiments in other solvents do not correspond to the simulated pattern of (2) and show a dependence on the solvent used. This may indicate formation of alternative solvated co-crystal phases, although diffraction quality crystals could not be obtained.

PXRD data for the polycrystalline products of screening for CCF formation were collected using a Bruker D8 Discover diffractometer, operating in transmission geometry with $\mathrm{Cu} \mathrm{K} \alpha$ radiation $(\lambda=1.5418$ $\AA$ ) and fitted with a Göbel X-ray focusing mirror and a LynxEye linear detector. Finely ground samples of each of the products of screening were contained in a 96-well plate. Data for each sample were collected over the angular range $4 \leq 2 \theta /{ }^{\circ} \leq 50$, counting for $0.25 \mathrm{~s}$ at each 0.02019 increment of the detector position.

Single crystal X-ray diffraction data for the co-crystals were collected using a Bruker Nonius X8-Apex2 CCD diffractometer operating with graphite-monochromatized Mo $\mathrm{K} \alpha$ radiation $(\lambda=0.710173 \AA$ ) $)$. An Oxford Cryosystems Cryostream was used to cool the crystals to 100 $\mathrm{K}$ prior to data collection. Data were processed using the manufacturer's standard routines. ${ }^{32}$ The crystal structures were solved by direct methods using the program SHELXS, ${ }^{33}$ and subsequent Fourier calculations and least-squares refinements were performed on $F$ using the program CRYSTALS. ${ }^{34}$ All non-hydrogen atoms were refined with anisotropic displacement parameters. All hydrogen atoms bonded to the carbon atoms were placed geometrically and refined with the isotropic displacement parameter fixed at 1.5 times $U_{\text {eq }}$ of the atoms to which they are attached. Protons involved in hydrogen bonding were located directly via inspection of difference Fourier maps and were refined isotropically.

Infrared spectroscopic data for co-crystals 1-3 were obtained using a Perkin-Elmer 100 ATR spectrometer. Ground crystals of co-crystals 1-3 were placed on the crystal plate of the infrared instrument and the spectrum was recorded in diffuse reflectance geometry. Differential scanning calorimetric data for the samples 1-3 were obtained using a Seiko model DSC-6200 instrument. The samples were weighed into aluminum DSC pans and crimped with a pinhole on the lid. The samples were analyzed over the temperature range $25-280^{\circ} \mathrm{C}$, using a heating rate of $10{ }^{\circ} \mathrm{C}$. The data were processed using Muse Measurement v. 5.4 (Build 263) software.

Samples for ${ }^{1} \mathrm{H}$ NMR were dissolved in DMSO- $d_{6}$ and spectra obtained using a Bruker $300 \mathrm{MHz}$ spectrometer. The ${ }^{1} \mathrm{H}$ NMR spectrum was recorded to confirm the API/CCF ratio in the bulk material. ${ }^{1} \mathrm{H}$ chemical shift values are reported on the $\delta$ scale.${ }^{1} \mathrm{H}$ NMR (300 MHz, DMSO- $d_{6}$ ) of the co-crystal (1): $\delta 9.64(\mathrm{~s}, 2 \mathrm{H}), 7.32$ and $6.66\left(\mathrm{AA}^{\prime} \mathrm{XX}^{\prime}, 2 \times 4 \mathrm{H}\right), 3.97$ (br. s, $\left.6 \mathrm{H}\right), 2.45(\mathrm{~m}, 2 \mathrm{H}), 1.97(\mathrm{~s}$ 
$6 \mathrm{H}), 1.68(\mathrm{~m}, 4 \mathrm{H}), 1.00(\mathrm{~m}, 4 \mathrm{H}) .{ }^{1} \mathrm{H}$ NMR (DMSO-d $)_{6}$ of co-crystal (2): 9.65 (s, 2H), 9.16 (br. s, $2 \mathrm{H}), 8.60$ and $7.60\left(\mathrm{AA}^{\prime} \mathrm{XX}^{\prime}, 2 \times 4 \mathrm{H}\right)$, $7.53(\mathrm{~s}, 2 \mathrm{H}), 7.34$ and $6.68\left(\mathrm{AA}^{\prime} \mathrm{XX}^{\prime}, 2 \times 4 \mathrm{H}\right), 4.13(\mathrm{~s}, 1 \mathrm{H}), 3.17(\mathrm{~s}$, $3 \mathrm{H}), 1.97(\mathrm{~s}, 6 \mathrm{H}) .{ }^{1} \mathrm{H}$ NMR (DMSO- $\left.d_{6}\right)$ of co-crystal $(3): \delta 9.66(\mathrm{~s}$, $2 \mathrm{H}), 9.15(\mathrm{~s}, 2 \mathrm{H}), 8.44$ and $7.25\left(\mathrm{AA}^{\prime} \mathrm{XX}^{\prime}, 2 \times 4 \mathrm{H}\right), 7.33$ and 7.25 $\left(\mathrm{AA}^{\prime} \mathrm{XX}^{\prime}, 2 \times 4 \mathrm{H}\right), 2.94(\mathrm{~s}, 8 \mathrm{H}), 1.97(\mathrm{~s}, 6 \mathrm{H})$.

\section{RESULTS AND DISCUSSION}

A summary of the results of the search of the CSD is presented in Table 2. The database search was conducted to find complementary co-crystal formers targeting the phenolic $\mathrm{OH}-$ group of paracetamol. The results of the CSD search are presented in two categories: raw and refined. The former refers to the search results for a specified functional group(s) including those occurrences where other functional groups may be present, whereas the latter contains those results for which there are no additional functional group(s) in the immediate vicinity of those for which the search was conducted. The CSD search reveals 8009 crystal structures containing at least one phenolic $\mathrm{O}-\mathrm{H}$ moiety of which $13 \%$ exhibit the $\mathrm{OH} \cdot \cdots \mathrm{OH}$ supramolecular homosynthon. However, the remainder of the crystal structures in the search results are dominated by supramolecular heterosynthons. The CSD analysis reveals that of those structures containing a phenolic hydroxyl group together with functional groups such as aromatic nitrogen atoms and amines, $42-52 \%$ involve supramolecular heterosynthon formation, even in the presence of other functional groups. In the absence of other hydrogen bond donors or acceptors the percentages rise to $54 \%$ and $64 \%$ for aromatic nitrogen atoms and amines respectively. The search also reveals that for interactions of phenols with amides, in those cases where homosynthons are observed, the $\mathrm{CONH}_{2} \cdots \mathrm{CONH}_{2}$ homosynthon dominates over the $\mathrm{OH} \cdots \mathrm{OH}$ homosynthon, in both the raw and refined data. However, heterosynthons involving $\mathrm{O}-\mathrm{H} /$ amide interactions are predominant in the refined data. For the interactions of phenols with carboxylic acids, $\mathrm{OH} \cdots \mathrm{O}=\mathrm{C}(\mathrm{OH})$ supramolecular heterosynthons exhibit $56 \%$ reliability in the presence of competing functional groups, which increases to $67 \%$ in the absence of competing functional groups, while the analysis of phenol-amine interactions indicates that the $\mathrm{OH} \cdots \mathrm{NH}_{2}$ supramolecular heterosynthon is more common than the $\mathrm{OH} \cdots \mathrm{OH}$ supramolecular homosynthon. In summary, analysis of the CSD for structures in which there are noncovalent interactions between phenolic and other complementary functional groups reveals a marked preference for supramolecular heterosynthons over supramolecular homosynthons. Taking into account the percentage occurrence of supramolecular heterosynthons observed in the refined searches, molecules containing at least one of the functional groups of aromatic nitrogen group, amides, carbonyl groups, carboxylic acids, and amines were selected as potential cocrystal formers for screening studies (Table 1).

PXRD of the solids obtained from the liquid assisted grinding method of screening revealed physical mixtures of starting materials in most cases. In such cases the liquid phase may merely serve as a lubricant, which would be consistent with the lack of any dependence of the nature of the solid product on the choice of solvent. However, the reflections arising from the starting materials were absent when trans-1,4-diaminocyclohexane, 1,2-bis(4-pyridyl)ethane, and 1,2-di(4-pyridyl)ethylene are used as CCFs. PXRD data for the products of solvent-drop grinding experiments using 1,2-di(4-pyridyl)ethylene as CCF reveal that while reflections of the starting

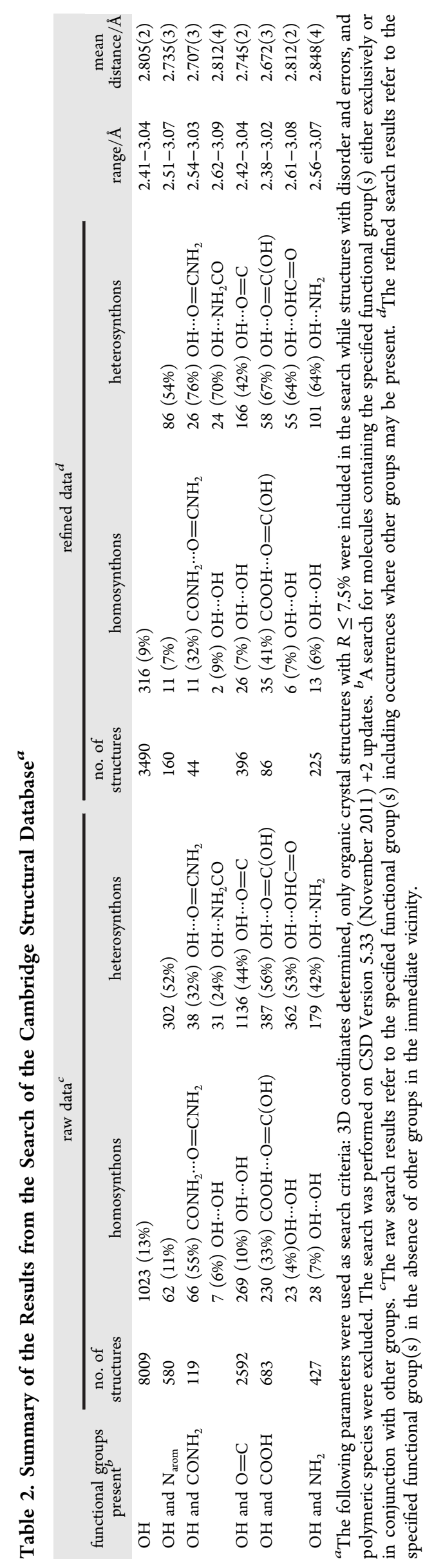


materials are absent regardless of the solvent used, a different solid phase is produced with each solvent. However, it has not been possible to obtain suitable single crystals of these new phases to study the detailed hydrogen bonding arrangement (see Supporting Information for experimental PXRD data).

The DSC data of the co-crystals reveal single sharp endotherms at $157.9,113.1$, and $116.6{ }^{\circ} \mathrm{C}$ for products $1-3$ respectively. These endotherms, which correspond to the melting point of the solids, occur at significantly different temperatures to those of paracetamol $\left(168-172{ }^{\circ} \mathrm{C}\right)$ or the cocrystal former (trans-1,4-diaminocyclohexane, $68-72{ }^{\circ} \mathrm{C}$; trans1,2-di-(4-pyridyl)-ethylene, $148-152{ }^{\circ} \mathrm{C}$; 1,2-bis(4-pyridyl)ethane, $110-112{ }^{\circ} \mathrm{C}$ ), indicating the formation of co-crystals and not simple physical mixtures. All three co-crystals described here have melting temperatures reduced from that of paracetamol, suggesting that the cohesive energy of co-crystals 1-3 is reduced from that of pure paracetamol form I.

Full crystallographic details for crystal structure determinations of the co-crystals $\mathbf{1 - 3}$ are presented in Table 3 . The

Table 3. Crystallographic Data for Co-Crystals 1-3

\begin{tabular}{|c|c|c|c|}
\hline & 1 & 2 & 3 \\
\hline $\begin{array}{l}\text { chemical } \\
\text { formula }\end{array}$ & $\mathrm{C}_{11} \mathrm{H}_{16} \mathrm{~N}_{2} \mathrm{O}_{2}$ & $\mathrm{C}_{29} \mathrm{H}_{32} \mathrm{~N}_{4} \mathrm{O}_{5}$ & $\mathrm{C}_{40} \mathrm{H}_{42} \mathrm{~N}_{6} \mathrm{O}_{4}$ \\
\hline $\begin{array}{l}\text { formula } \\
\text { weight }\end{array}$ & 208.26 & 516.59 & 670.8 \\
\hline crystal system & triclinic & triclinic & triclinic \\
\hline$a(\AA)$ & $5.0174(5)$ & $9.0546(2)$ & $8.9707(4)$ \\
\hline$b(\AA)$ & $8.8907(9)$ & $10.6241(2)$ & $12.8633(6)$ \\
\hline$c(\AA)$ & $12.7562(1)$ & $14.3162(3)$ & $16.8305(2)$ \\
\hline$\alpha\left(^{\circ}\right)$ & $106.21(4)$ & $82.97(3)$ & $106.06(2)$ \\
\hline$\beta\left(\left(^{\circ}\right)\right.$ & $91.40(5)$ & $89.69(3)$ & $95.27(2)$ \\
\hline$\gamma\left({ }^{\circ}\right)$ & $90.15(5)$ & $73.85(3)$ & $95.13(3)$ \\
\hline space group & $P \overline{1}$ & $P \overline{1}$ & $P \overline{1}$ \\
\hline$V / \AA^{3}$ & $546.2(1)$ & $1312.3(5)$ & $1844.8(1)$ \\
\hline Z & 2 & 2 & 2 \\
\hline $\begin{array}{l}N_{\text {reflection }} / \\
N_{\text {parameter }}\end{array}$ & $4141 / 136$ & $4904 / 343$ & $4389 / 469$ \\
\hline$\rho_{\text {calc }} / \mathrm{g} \mathrm{cm}^{-3}$ & 1.266 & 1.307 & 1.208 \\
\hline radiation type & $\begin{array}{c}\text { Mo } \operatorname{K} \alpha(\lambda= \\
0.710173 \AA)\end{array}$ & $\begin{array}{c}\text { Mo } \mathrm{K} \alpha(\lambda= \\
0.710173 \AA \AA)\end{array}$ & $\begin{array}{c}\text { Mo } \mathrm{K} \alpha(\lambda= \\
0.710173 \AA)\end{array}$ \\
\hline$T / \mathrm{K}$ & 100 & 100 & 293 \\
\hline$\theta$ range $/^{\circ}$ & $2-40$ & $1-27$ & $2-27$ \\
\hline range of $h$ & -8 to 8 & -9 to 11 & -11 to 11 \\
\hline range of $k$ & -15 to 15 & -17 to 18 & -16 to 16 \\
\hline range of $l$ & -18 to 21 & -13 to 11 & -16 to 21 \\
\hline Rmerge & 0.019 & 0.023 & 0.028 \\
\hline$R_{1}(\%)$ & 3.75 & 4.18 & 5.44 \\
\hline$W R_{2}(\%)$ & 4.24 & 4.34 & 5.67 \\
\hline $\begin{array}{l}\text { goodness-of- } \\
\text { fit }\end{array}$ & 1.072 & 1.117 & 1.102 \\
\hline
\end{tabular}

local coordination and atom numbering scheme for each of the three co-crystals is presented in Figure 3. Selected bond distances and angles are presented as Supporting Information while geometric parameters of the hydrogen bonds are reported in Table 3, together with those for paracetamol. Co-crystal (1) contains one molecule of paracetamol and half a molecule of trans-1,4-diaminocyclohexane in the asymmetric unit (Figure 3a). $\mathrm{N}(2)-\mathrm{H}(2) \cdots \mathrm{O}(2)$ hydrogen bonding interactions between paracetamol molecules lead to the formation of infinite chains, which may be denoted C(4), directed along [100] (Figure 4)]. These chains are then cross-linked in the

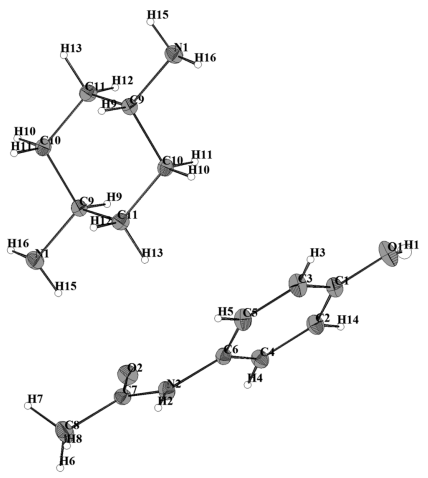

(b)

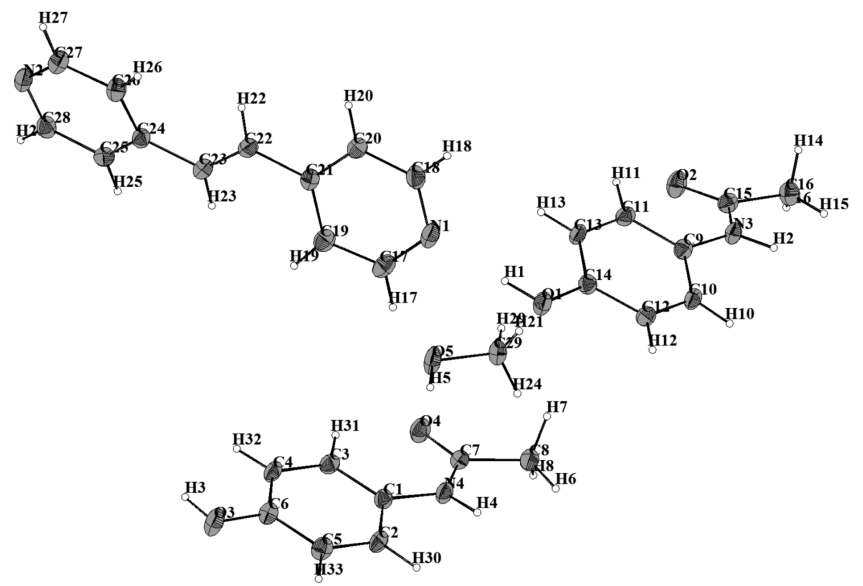

(c)
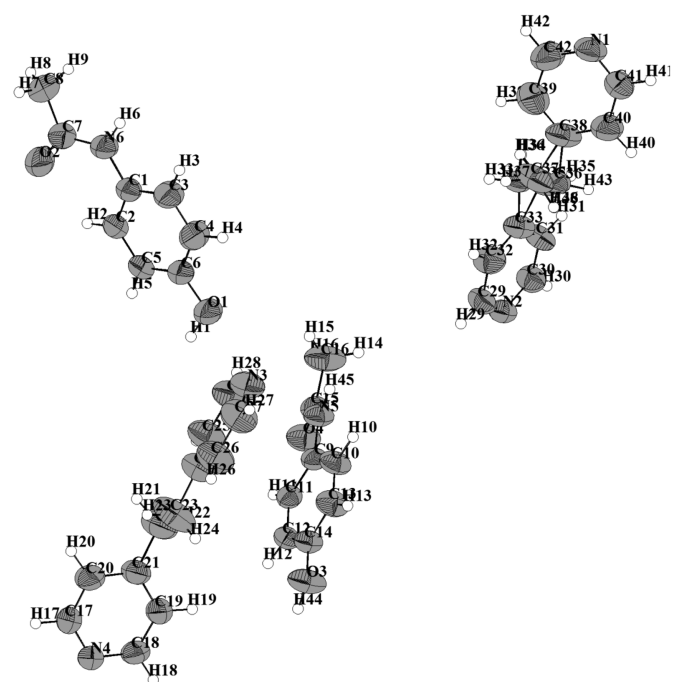

Figure 3. Local coordination of the non-hydrogen atoms in the cocrystals of paracetamol with (a) trans-1,4-diaminocyclohexane, (1); (b) trans-1,4-di(4-pyridyl)ethylene, (2); 1,2-bis(4-pyridyl)ethane, (3). The displacement ellipsoids are drawn at the $50 \%$ probability level and atoms in the asymmetric unit are labeled.

[110] direction through $\mathrm{O}(1)-\mathrm{H}(1) \cdots \mathrm{N}(1)$ and $\mathrm{N}(1)-$ $\mathrm{H}(16) \cdots \mathrm{O}(1)$ hydrogen bonding interactions to create a twodimensional (2D) hydrogen bonded network (Figure 4). Along with several weak interactions there is an additional $\mathrm{N}(1)-$ $\mathrm{H}(15) \cdots \mathrm{O}(2)$ interaction between the $2 \mathrm{D}$ networks which extend the structure into the third dimension.

Co-crystal (2) contains in the asymmetric unit two molecules of paracetamol, one molecule of trans-1,2-di-(4-pyridyl)ethylene, and one molecule of methanol (Figure 3b). Pairs of crystallographically distinct paracetamol molecules are linked 


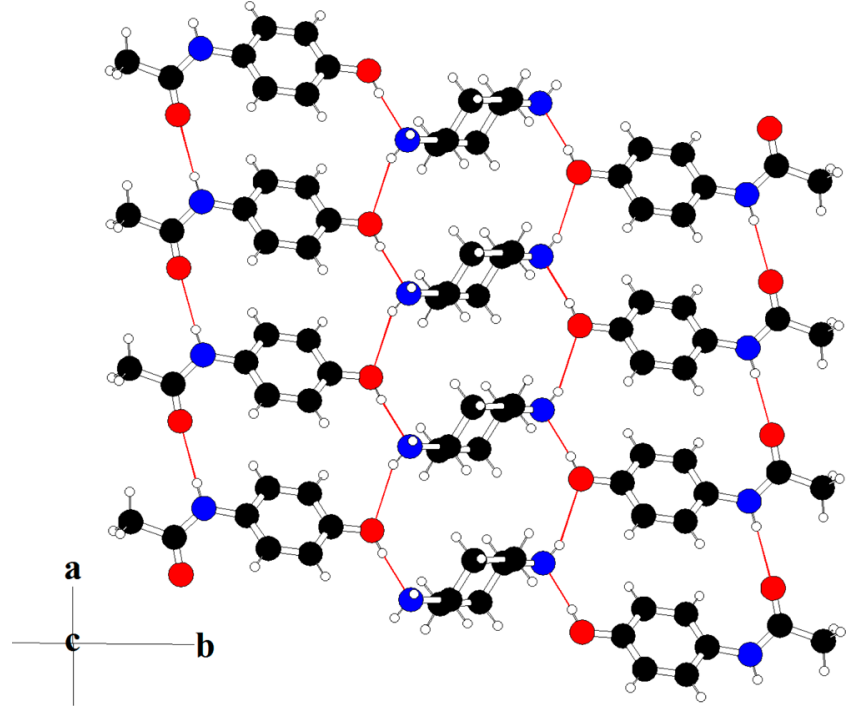

Figure 4. The structure of cocrystal (1) viewed along [001]. Key: as for Figure 1.

through $\mathrm{N}(4)-\mathrm{H}(4) \cdots \mathrm{O}(2)$ intermolecular hydrogen bonding interactions to form dimeric units, neighboring pairs of which are connected through $\mathrm{N}(3)-\mathrm{H}(2) \cdots \mathrm{O}(5)$ and $\mathrm{O}(5)-$ $\mathrm{H}(5) \cdots \mathrm{O}(4)$ hydrogen bonds involving the methanol solvent incorporated in the co-crystal. This produces paracetamolmethanol chains directed approximately along [110]. The cocrystal former trans-1,2-di-(4-pyridyl)-ethylene serves to crosslink these chains through $\mathrm{O}(1)-\mathrm{H}(1) \cdots \mathrm{N}(1)$ and $\mathrm{O}(3)-$ $\mathrm{H}(3) \cdots \mathrm{N}(2)$ hydrogen bonds (Figure 5, Table 4). The neighboring aromatic rings of trans-1,2-di-(4-pyridyl)-ethylene are arranged in a face to face ${ }^{35}$ stacking fashion with a slip angle of $18.2^{\circ}$ with a centroid to centroid distance of around $3.32 \AA$. Aromatic interactions of this kind are known to generate supramolecular synthons and have been exploited for co-crystal synthesis. ${ }^{36}$ These paired units are then linked through several weak interactions between the $2 \mathrm{D}$ networks to stabilize the cocrystal to extend into the third dimension.

The asymmetric unit of the co-crystal (3) consists of four independent molecules, two each of paracetamol and the cocrystal former 1,2-bis(4-pyridyl)ethane (Figure 3c). Analogous to co-crystals (1) and (2) the phenolic $-\mathrm{OH}$ and amidic $-\mathrm{NH}$
Table 4. Geometric Parameters for the Hydrogen Bonds in Paracetamol (PAC) and the Co-Crystals 1-3

\begin{tabular}{|c|c|c|c|c|c|}
\hline compound & hydrogen bond & $\begin{array}{c}d \\
(\mathrm{H} \cdots \mathrm{A}) \\
(\AA)\end{array}$ & $\begin{array}{c}d \\
(\mathrm{D} \cdots \mathrm{A}) \\
(\AA)\end{array}$ & $\begin{array}{c}\theta(\mathrm{D}- \\
\mathrm{H} \cdots \mathrm{A}) \\
\left(^{\circ}\right)\end{array}$ & $\begin{array}{c}(\mathrm{H} \cdots \mathrm{A}) \mathrm{vdW} \\
\text { cutoff } \\
\text { contraction } \\
(\%)\end{array}$ \\
\hline PAC & $\mathrm{N}-\mathrm{H} \cdots \mathrm{O}$ & 2.00 & 2.91 & 163.8 & 26 \\
\hline PAC & $\mathrm{O}-\mathrm{H} \cdots \mathrm{O}=\mathrm{C}$ & 1.77 & 2.66 & 166.1 & 36 \\
\hline (1) & $\begin{array}{l}\mathrm{N}(2)- \\
\mathrm{H}(2) \cdots \mathrm{O}(2)\end{array}$ & 2.06 & 2.96 & 174.1 & 23 \\
\hline (1) & $\begin{array}{l}\mathrm{O}(1)- \\
\mathrm{H}(1) \cdots \mathrm{N}(1)\end{array}$ & 1.81 & 2.68 & 169.9 & 33 \\
\hline (1) & $\begin{array}{l}\mathrm{N}(1)- \\
\mathrm{H}(16) \cdots \mathrm{O}(1)\end{array}$ & 2.26 & 3.15 & 169.9 & 17 \\
\hline (1) & $\begin{array}{l}\mathrm{N}(1)- \\
\mathrm{H}(15) \cdots \mathrm{O}(2)\end{array}$ & 2.32 & 3.16 & 158.0 & 15 \\
\hline (2) & $\begin{array}{l}\mathrm{O}(1)- \\
\mathrm{H}(1) \cdots \mathrm{N}(1)\end{array}$ & 1.85 & 2.78 & 177.9 & 33 \\
\hline (2) & $\begin{array}{l}\mathrm{N}(3)- \\
\quad \mathrm{H}(2) \cdots \mathrm{O}(5)\end{array}$ & 1.93 & 2.83 & 162.9 & 29 \\
\hline (2) & $\begin{array}{l}\mathrm{O}(3)- \\
\mathrm{H}(3) \cdots \mathrm{N}(2)\end{array}$ & 1.85 & 2.71 & 169.8 & 33 \\
\hline (2) & $\begin{array}{l}\mathrm{N}(4)- \\
\mathrm{H}(4) \cdots \mathrm{O}(2)\end{array}$ & 1.99 & 2.90 & 173.8 & 27 \\
\hline (2) & $\begin{array}{l}\mathrm{O}(5)- \\
\mathrm{H}(5) \cdots \mathrm{O}(4)\end{array}$ & 1.76 & 2.72 & 173.8 & 35 \\
\hline (3) & $\begin{array}{l}\mathrm{O}(1)- \\
\mathrm{H}(1) \cdots \mathrm{N}(4)\end{array}$ & 1.75 & 2.71 & 166.6 & 36 \\
\hline (3) & $\begin{array}{l}\mathrm{N}(6)- \\
\mathrm{H}(6) \cdots \mathrm{N}(3)\end{array}$ & 2.02 & 2.99 & 166.4 & 26 \\
\hline (3) & $\begin{array}{l}\mathrm{O}(3)- \\
\mathrm{H}(44) \cdots \mathrm{N}(2)\end{array}$ & 1.77 & 2.75 & 175.8 & 35 \\
\hline (3) & $\begin{array}{l}\mathrm{N}(5)- \\
\mathrm{H}(45) \cdots \mathrm{N}(1)\end{array}$ & 1.98 & 2.96 & 175.5 & 28 \\
\hline
\end{tabular}

${ }^{a} \mathrm{D}$ refers to the proton donor, A refers to the proton acceptor, $d$ are distances in $\AA$. The atom numbering scheme is that presented in Figure 3.

of paracetamol are involved in hydrogen bonding. While in cocrystals (1) and (2) it is only the phenolic $-\mathrm{OH}$ that is hydrogen bonded to the CCF, here the amidic $\mathrm{N}-\mathrm{H}$ is also hydrogen bonded to the CCF. However, the carbonyl groups of paracetamol are not involved in conventional hydrogen bonds but participate in weak $\mathrm{C}-\mathrm{H} \cdots \mathrm{O}$ interactions between molecules related by an inversion center. The paracetamol molecules are linked to two 1,2-bis(4-pyridyl)ethane molecules, through $\mathrm{O}(1)-\mathrm{H}(1) \cdots \mathrm{N}(4)$ and $\mathrm{N}(6)-\mathrm{H}(6) \cdots \mathrm{N}(3)$ interac-

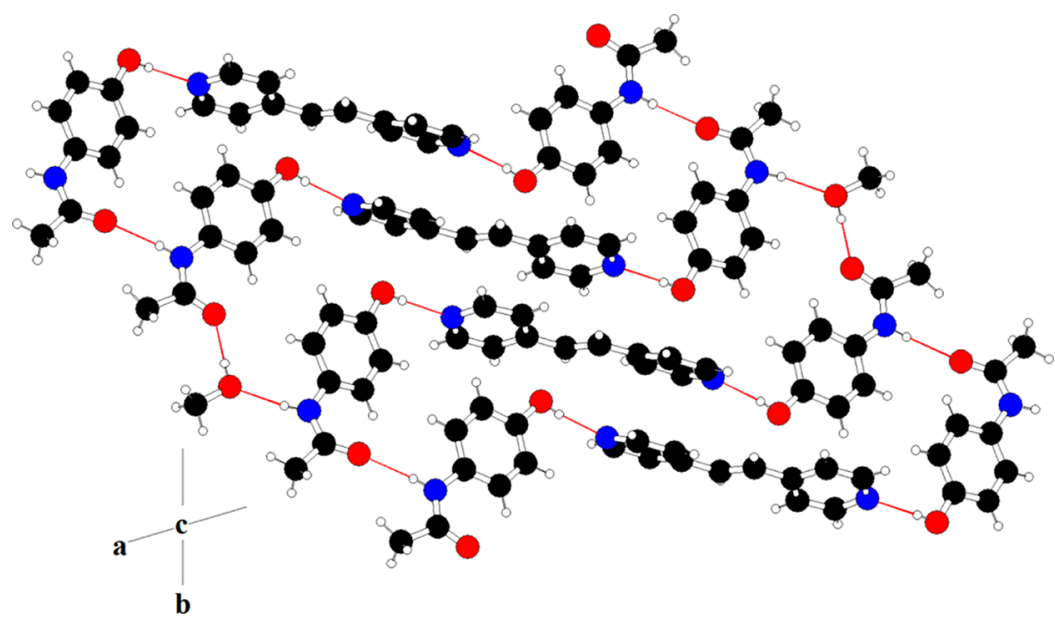

Figure 5. The structure of cocrystal (2) viewed along [001]. Key: as for Figure 1. 


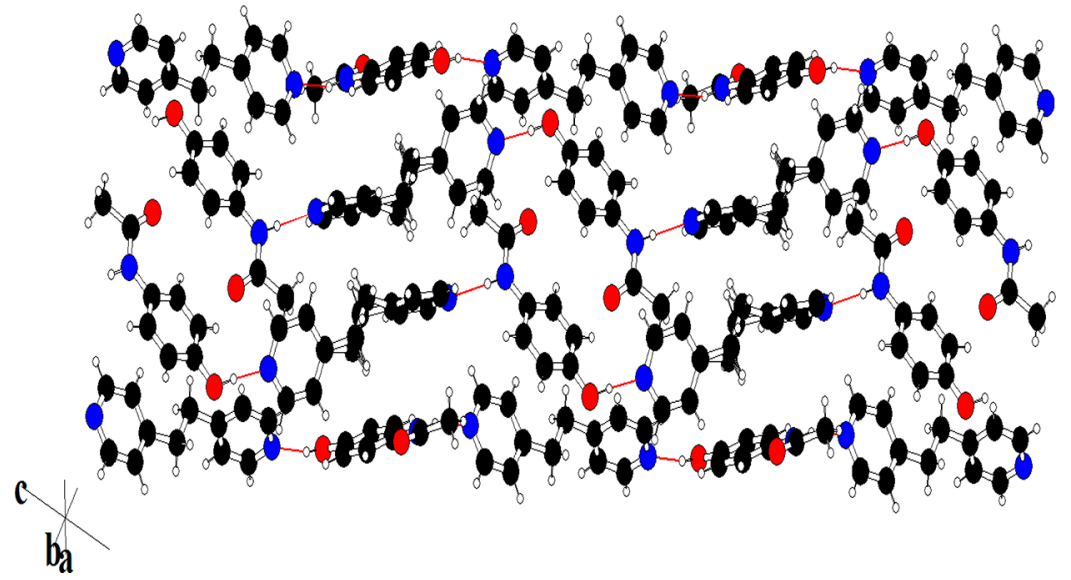

Figure 6. The structure of co-crystal (3). Key: as Figure 1.

Table 5. Bond Stretching Frequencies in Paracetamol and the Three Co-Crystals, Determined by Infrared Spectroscopy

\begin{tabular}{lcccc}
\multicolumn{1}{c}{ assignment } & paracetamol in gas-phase ${ }^{42}$ & paracetamol Form I & (1) & (2) \\
$\nu(\mathrm{O}-\mathrm{H}) / \mathrm{cm}^{-1}$ & 3653 & 3160 & 3326 & 3070 \\
$\nu(\mathrm{N}-\mathrm{H}) / \mathrm{cm}^{-1}$ & 3465 & 3324 & 3326,3273 & 3290 \\
$\nu(\mathrm{C}-\mathrm{H})_{\text {aromatic }} / \mathrm{cm}^{-1}$ & 3034 & 2895 & 3049 & 3246 \\
$\nu(\mathrm{C}=\mathrm{O}) / \mathrm{cm}^{-1}$ & 1721 & 1651 & 1636 & 2870 \\
\hline
\end{tabular}

tions in one crystallographically independent molecule and $\mathrm{O}(3)-\mathrm{H}(44) \cdots \mathrm{N}(2)$ and $\mathrm{N}(5)-\mathrm{H}(45) \cdots \mathrm{N}(1)$ interactions in the other (Table 3 ). This produces two crystallographicallydistinct stepped chains of molecules (Figure 6). The $\mathrm{CH}_{2}$ groups in one of the crystallographically independent 1,2-bis(4pyridyl)ethane molecules were found to be disordered over two sites and were refined anisotropically with occupancies of 0.47 and 0.53 . Several weak $\mathrm{C}-\mathrm{H} \cdots \mathrm{O}$ interactions between these one-dimensional chains extend the structure into a threedimensional structure.

The paracetamol molecule contains two hydrogen bond donors; the phenolic $\mathrm{O}-\mathrm{H}$ and the amidic $\mathrm{N}-\mathrm{H}$ groups and two acceptors; the amidic and phenolic oxygen atoms. A reasonable expectation would be for the strongest hydrogen bonds to be formed between the best donor and best acceptor. During co-crystal formation the donors and acceptors of paracetamol are in competition with those of the co-crystal former and the structure adopted is that which optimizes the donor-acceptor interactions in the co-crystal. Geometric parameters of the hydrogen bonds in co-crystals 1-3 are presented in Table 3. The strong $\mathrm{O}-\mathrm{H} \cdots \mathrm{O}=\mathrm{C}$ interactions $(d(\mathrm{D} \cdots \mathrm{A})=2.66 \AA)$ present in paracetamol are absent in the co-crystals. However, they are replaced by $\mathrm{O}-\mathrm{H} \cdots \mathrm{N}$ interactions which operate over a similar distance and are therefore of comparable strength. This is supported by the similarity in the contraction of the $\mathrm{H} \cdot \cdots \mathrm{A}$ van der Waals' cutoff and red shift of the $\nu(\mathrm{D}-\mathrm{H})$ stretching frequencies (vide infra). The geometric and spectroscopic data are consistent with the strongest hydrogen bonds in the co-crystals resulting from these $\mathrm{O}-\mathrm{H} \cdots \mathrm{N}$ interactions. Consistent with the suggestions of Etter $^{37}$ all of the remaining proton donors and acceptors also participate in hydrogen bond formation, as evidenced in all three co-crystals by the $\mathrm{N}-\mathrm{H} \cdot \cdot \mathrm{O}=\mathrm{C}$ interactions between paracetamol molecules, which are of similar strength to those in paracetamol itself. Co-crystal (2) has additional hydrogen bonds $\mathrm{N}-\mathrm{H} \cdots \mathrm{O}$ and $\mathrm{O}-\mathrm{H} \cdots \mathrm{O}=\mathrm{C}$ due to the incorporation of solvent molecules. This suggests a hierarchy of hydrogen bonds in the co-crystals $\mathbf{1 - 3}$ which is in accord with the empirical rules proposed by Etter. ${ }^{37}$

Complexes with hydrogen bonds are stabilized by electrostatic, polarization, induction, and dispersion energy terms. From an electrostatic viewpoint, the interaction may be considered to have contributions from interactions between monopoles, dipoles, quadrupoles, etc., each of which has a different characteristic cutoff in terms of distance. One common means of assigning the character of the hydrogen bond is the contraction, with respect to the sum of the van der Waals' radii, of the $\mathrm{H} \cdots$ A distance. Proton-centered hydrogen bonds typically exhibit a contraction of between 40 and 55\% of the sum of the van der Waals' radii. ${ }^{38}$ In co-crystals $1-3$ the van der Waals' cutoff contraction lies between 20 and 40\% (Table 3 ), which suggests these hydrogen bonds may be classed as being of moderate strength ${ }^{38}$ in which the electrostatic interaction terms are dominant. It has been empirically established that hydrogen bonds become increasingly linear with increasing strength, as linearity optimizes the electrostatic component (dipole-monopole, dipole-dipole) of the interaction. The electrostatic contribution to the intermolecular interaction tends to dominate and imparts directionality on hydrogen bonds. This is particularly significant in short and proton-centered hydrogen-bonds, whose typical angular range is $160 \leq \theta /{ }^{\circ} \leq 180$, but also applies to longer bonds of electrostatic nature. According to Reed et al., ${ }^{39}$ charge transfer between donor and acceptor groups has a strong influence on the geometrical and spectral properties of the co-crystals. In particular, in a $\mathrm{D}-\mathrm{H} \cdots \mathrm{A}$ hydrogen bond there is charge transfer from lone pairs or $\pi$-molecular orbitals of the electron donor (proton acceptor) to the antibonding orbitals of the $\mathrm{D}-\mathrm{H}$ bond of the electron acceptor (proton donor). An increase of electron density in the antibonding orbitals elongates the $\mathrm{D}-\mathrm{H}$ bond, which causes the red-shift of the D-H stretching frequency. Therefore charge transfer and hence hydrogenbond formation may be inferred from comparison of characteristic vibrational frequencies of a free R-D-H group 
with that of the same group in the presence of a hydrogen bond acceptor. The characteristic vibrational frequencies of the three co-crystals 1-3 and of crystalline paracetamol form I may be compared with those observed in the gas phase infrared spectrum of paracetamol (Table 5). The frequencies of the $\nu(\mathrm{O}-\mathrm{H}), \nu(\mathrm{N}-\mathrm{H})$, and $\nu(\mathrm{C}=\mathrm{O})$ stretching vibrations in cocrystals 1-3 and in paracetamol form I are red-shifted by up to $16 \%$ relative to the equivalent vibrations in the gas-phase spectrum of paracetamol. From the crystal structure determination, it can be deduced that the lone pair of the nitrogen atom of each of the co-crystal formers is aligned along the axis of the $\mathrm{O}-\mathrm{H}$ bond of the hydroxyl group of paracetamol, thereby facilitating charge transfer between the donor and acceptor pair. Therefore, we conclude that both electrostatic and charge transfer terms influence the directional behavior of the hydrogen bonds in co-crystals 1-3.

In all three co-crystals presented here, the structural and spectroscopic data indicate that the hydrogen bonds formed between the API and the CCF are of comparable strength to those originally present in the API. All three co-crystals studied here have the same, i.e., $\mathrm{O}-\mathrm{H} \cdots \mathrm{N}$ supramolecular heterosynthon between the API and CCF. However in structure (3) in addition to the $\mathrm{O}-\mathrm{H} \cdots \mathrm{N}$ there is a $\mathrm{N}-\mathrm{H} \cdots \mathrm{N}$ supramolecular interaction observed between the API and CCF. Our investigations show that difunctional CCFs, able to form chain-like structural motifs through distinct hydrogen bonds, are necessary for co-crystal formation with paracetamol. This is in accordance with previously reported CCFs in multicomponent crystalline forms of paracetamol. Although CSD analysis suggests carboxylic acids and amides as potential cocrystal formers, our experiments demonstrate that they are not effective for paracetamol. This may be due to the selfcomplementary hydrogen bonding nature of these functional groups, which favors homosynthon formation. A hierarchical arrangement between the best donor of paracetamol to the best acceptor in CCF is observed in all the co-crystals presented here and is indeed observed in almost all of the previously reported co-crystal forms of paracetamol. Of the reported cocrystals of paracetamol, only those involving theophylline and bipyridine $^{29}$ do not follow the hierarchical arrangement of hydrogen bonding. In the case of the paracetamol-bipyridine co-crystal, strong $\pi-\pi$ interactions (at a distance of ca. $3.4 \AA$ ) between the pyridine moieties of bipyridine stabilize the crystal structure in co-operation with the hydrogen bonds. In the case of the paracetamol-theophylline co-crystal, the best acceptor of theophylline, the imidazole nitrogen atom, does not participate in conventional hydrogen bonds. The two molecules are arranged such that they form flat hydrogen bonded sheets.

A generally accepted guideline ${ }^{40}$ is that proton transfer will occur from an acid to a base when the difference in $\mathrm{p} K_{\mathrm{a}}$ (where $\Delta \mathrm{p} K_{\mathrm{a}}$ refers to the difference between the $\mathrm{p} K_{\mathrm{a}}$ value of a protonated base and that of the acid) is $>3.5$, and a neutral cocrystal will form when the $\Delta \mathrm{p} K_{\mathrm{a}}<0$. A co-crystal to salt continuum $^{30 \mathrm{~d}}$ exists between $0 \leq \Delta \mathrm{p} K_{\mathrm{a}} \leq 3.5$. The ambiguity in this range of $\Delta \mathrm{p} K_{\mathrm{a}}$ values may be a problem when applying crystal engineering principles to co-crystal formation, as the charge separation resulting from salt formation leads to the dominance of electrostatic interactions over the noncovalent interactions, on which crystal engineering is based. Moreover, the prediction of the degree of proton transfer in the solid-state form based on the $\mathrm{p} K_{\mathrm{a}}$ difference remains imprecise and may also show variations with the solvent of crystallization. Calculated $\mathrm{pK}_{\mathrm{a}}$ values ${ }^{41}$ of the CCFs used in this work indicate that neither the amine nor pyridyl CCFs investigated are sufficiently basic to form a salt with paracetamol through complete proton transfer. Calculated values $\Delta \mathrm{p} K_{\mathrm{a}}$ of $<0$ are thus consistent with the formation of a neutral complex.

\section{CONCLUSIONS}

Analysis of structural data in the Cambridge Structural Database resulted in the identification of a range of potential co-crystal formers compatible with paracetamol. Subsequent screening using solvent-drop grinding in conjunction with highthroughput PXRD led to the discovery of three new co-crystals of paracetamol. All the three co-crystals presented here utilize the $\mathrm{O}-\mathrm{H} \cdots \mathrm{N}$ supramolecular heterosynthon. The ability of phenols to form this heterosynthon is consistent with the results of the analysis of the structural database, suggesting the approach may be applicable to a wider range of phenol derivatives. Comparison of the geometric and spectroscopic parameters of the hydrogen-bonds in co-crystals 1-3 with those for paracetamol reveals that they are of similar strength, irrespective of the chemical identity of the synthon. The study shows that a balance between the retrosynthetic approach (synthon method) and database screening of supramolecular synthons provides a useful approach to the targeted synthesis.

\section{ASSOCIATED CONTENT}

\section{Supporting Information}

Crystallographic information files, CSD search details, DSC, NMR and IR spectra, powder diffraction patterns of screening experiments using trans-1,2-di-(4-pyridyl)-ethylene as CCF, comparison plot between single crystal simulated and bulk powder patterns, calculated $\mathrm{p} K_{\mathrm{a}}$ values of paracetamol and CCFs. This information is available free of charge via the Internet at http://pubs.acs.org/.

\section{AUTHOR INFORMATION}

\section{Corresponding Author}

*Tel: +44 131451 8034. Fax: +44 (0)131 451 3180. E-mail: a. v.powell@hw.ac.uk.

\section{Notes}

The authors declare no competing financial interest.

\section{ACKNOWLEDGMENTS}

The authors wish to thank the Scottish Funding CouncilSPIRIT programme and Heriot-Watt University for funding.

\section{REFERENCES}

(1) Bond, A. D. CrystEngComm 2007, 9, 833.

(2) Buck, J. S.; Ide, W. S. J. Am. Chem. Soc. 1931, 53, 2784.

(3) Anderson, J. S. Nature 1937, 140, 583.

(4) Hall, B.; Devlin, J. P. J. Phys. Chem. 1967, 71, 465.

(5) Desiraju, G. R. CrystEngComm 2003, 5, 466.

(6) Jack, J. D. CrystEngComm 2003, 5, 506.

(7) Byrn, S. R.; Pfeiffer, R. R.; Stowell, J. G. Solid State Chemistry of Drugs, 2nd ed.; SSCI Inc.: IN, 1999.

(8) (a) Bernstein, J. Polymorphism in Molecular Crystals; Clarendon Press: Oxford, 2002. (b) Davey, R. J. Chem. Commun. 2003, 13, 1463. (c) Rogers, R. D. Cryst. Growth Des. 2004, 4, 1085.

(9) (a) Vishweshwar, P.; Beauchamp, D. A.; Zaworotko, M. J. Cryst. Growth Des. 2006, 6, 2429. (b) Mondal, R.; Howard, J. A. K.; Banerjee, R.; Desiraju, G. R. Cryst. Growth Des. 2006, 6, 2507. (c) Banerjee, R.; Bhatt, P. M.; Desiraju, G. R. Cryst. Growth Des. 2006, 6, 1468. (d) Barnett, S. A.; Tocher, D. A.; Vickers, M. CrystEngComm 2006, 8, 313. (e) Hosokawa, T.; Datta, S.; Sheth, A. R.; Brooks, N. R.; Young, V. G.; Grant, D. J. W. Cryst. Growth Des. 2004, 4, 1195. 
(10) (a) Vishweshwar, P.; McMahon, J. A.; Bis, J. A.; Zaworotko, M. J. J. Pharm. Sci. 2006, 95, 499. (b) Vishweshwar, P.; McMahon, J. A.; Peterson, M. L.; Hickey, M. B.; Shattock, T. R.; Zaworotko, M. J. Chem. Commun. 2005, 4601. (c) Fleischman, S. G.; Kuduva, S. S.; McMahon, J. A.; Moulton, B.; Bailey Walsh, R. D.; RodriguezHornedo, N.; Zaworotko, M. J. Cryst. Growth Des. 2003, 3, 909.

(d) Reddy, L. S.; Babu, N. J.; Nangia, A. Chem. Commun. 2006, 1369.

(e) Childs, S. L.; Hardcastle, K. I. Cryst. Growth Des. 2007, 7, 1291.

(f) Childs, S. L.; Chyall, L. J.; Dunlap, J. T.; Smolenskaya, V. N.; Stahly, B. C.; Stahly, G. P. J. Am. Chem. Soc. 2004, 126, 13335.

(11) (a) Stahl, P. H.; Nakano, M. In Handbook of Pharmaceutical Salts: Properties, Selection, and Use; Stahl, P. H.; Wermuth, C. G., Eds.; Wiley-VCH: New York, 2002; Ch. 4. (b) Berge, S. M.; Bighley, L. D.; Monkhouse, D. C. J. Pharm. Sci. 1977, 66, 1.

(12) Oswald, I. D. H.; Allan, D. R.; McGregor, P. A.; Motherwell, W. D. S.; Parsons, S.; Pulham, C. R. Acta Crystallogr., Sect. B 2002, 58, 1057.

(13) Almarsson, O; Zaworotko, M. J. Chem. Commun. 2004, 1889.

(14) Rodriguez-Spong, B.; Price, C. P.; Jayasankar, A.; Matzger, A. J.; Rodriguez-Hornedo, N. Adv. Drug Delivery Rev. 2004, 56, 241.

(15) Blagden, N.; De Matas, M.; Gavan, P. T.; York, P. Adv. Drug. Delivery Rev. 2007, 59, 617.

(16) Desiraju, G. R. Crystal Engineering. The Design of Organic Solids; Elsevier: Amsterdam, 1989.

(17) Pepinsky, R. Phys. Rev. 1955, 100, 971.

(18) Schmidt, G. M. J. Pure Appl. Chem. 1971, 27, 647.

(19) Thomas, J. M. Phil. Trans. R. Soc. Lond. A 1974, 277, 251.

(20) Dunitz, J. D. Pure Appl. Chem. 1991, 63, 177.

(21) Desiraju, G. R. Angew. Chem., Int. Ed. 1995, 34, 2311.

(22) Shattock, T. S.; Arora, K. K.; Vishweshwar, P.; Zaworotko, M. J. Cryst. Growth Des. 2008, 8, 4533.

(23) The method of search for existing cocrystals: The search was conducted using the parameters option "number of chemical units" as more than or equal to two. Hydrates and solvates were excluded from the search.

(24) (a) Allen, F. H.; Raithby, P. R.; Shields, G. P.; Taylor, R. Chem. Commun. 1998, 1043. (b) Allen, F. H.; Motherwell, W. D. S.; Raithby, P. R.; Shields, G. P.; Taylor, R. New. J. Chem. 1999, 23, 25.

(25) (a) Drebushchak, T. N.; Boldyreva, E. V. Z. Kristallogr. 2004, 219, 506. (b) Wilson, C. C. Z. Kristallogr. 2000, 215, 693.

(26) Burger, A. Acta Pharm. Technol 1982, 28, 1.

(27) Perrin, M-A; Neumann, M. A.; Elmaleh, H.; Zaska, L. Chem. Commun. 2009, 3181.

(28) Bernstein, J.; Davis, R. E.; Shimoni, L.; Chang, N. L. Angew. Chem. Int. Ed. 1995, 34, 1555.

(29) Karki, S.; Friscic, T.; Fabian, L.; Laity, P. R.; Day, G. M; Jones, W. Adv. Mater. 2009, 21, 3905.

(30) (a) Oswald, I. D. H.; Allan, D. R.; McGregor, P. A.; Motherwell, W. D. S; Parsons, S.; Pulham, C. R. Acta Crystallogr. Sect. B 2002, 58, 1057. (b) André, V.; Piedade, M. F. M; da; Duarte, M. T.. CrystEngComm 2012, 14, 5005. (c) Vrcelj, R. M.; Clark, N. I. B.; Kennedy, A. R.; Sheen, D. B.; Shepherd, E. E. A.; Sherwood, J. N. J. Pharm. Sci. 2003, 92, 2069. (d) Oswald, I. D. H.; Motherwell, W. D. S; Parsons, S.; Pulham, C. R. Acta Crystallogr. Sect. E 2002, 58, O1290.

(d) Oswald, I. D. H..; Pulham, C. R. CrystEngComm 2008, 10, 1114.

(e) Childs, S. L.; Stahly, G. P.; Park, A. Mol. Pharmaceutics 2007, 4, 323.

(31) Trask, A. V.; Motherwell, W. D. S; Jones, W. Chem Commun. 2004, 890 .

(32) APEX-2 software, Version 1.27; Bruker AXS Inc.: Madison, Wisconsin, USA, 2005.

(33) Sheldrick, G. M. Acta Crystallogr., Sect. A 2008, 64, 112.

(34) Betteridge, P. W.; Carruthers, J. R.; Cooper, R. I.; Prout, K.; Watkin, D. J. J. Appl. Crystallogr. 2003, 36, 1487.

(35) Collings, J. C.; Roscoe, K. P.; Thomas, R. Ll.; Batsanov, A. S.; Stimson, L. M.; Howard, J. A. K.; Marder, T. B. New J. Chem. 2001, 25, 1410.

(36) Salonen, L. M.; Ellermann, M.; Diedrich, F. Angew. Chem., Int. Ed. 2011, 50, 4808.
(37) Etter, M. C. Acc. Chem. Res. 1990, 23, 120.

(38) Gilli, G.; Gilli, P. The Nature of the Hydrogen Bond Outline of a Comprehensive Hydrogen Bond Theory; Oxford University Press: Oxford, 2009.

(39) Reed, A. E.; Curtiss, L. A.; Weinhold, F. Chem. Rev. 1988, 88, 899.

(40) Johnson, S. L.; Rumon, K. A. J. Phys. Chem. 1965, 69, 74.

(41) The SPARC program (http://archemcalc.com/sparc) uses computational algorithms based on fundamental chemical structure theory to estimate a variety of reactivity parameters. For some examples of the use of the SPARC program for $\mathrm{pKa}$ calculations, see (a) Erdemgil, F. Z.; Sanli, S.; Sanli, N.; Ozkan, G.; Barbosa, J.; Guiteras, J.; Beltran, J. L. Talanta 2007, 72, 489. (b) Hilal, S. H.; Karickhoff, S. W.; Carreira, L. A. Quant. Struct. Act. Rel. 1995, 14, 348. (c) Hilal, S. H.; ElShabrawy, Y.; Carreira, L. A.; Karickhoff, S. W.; Toubar, S. S. Talanta 1996, 43, 607. (d) Hilal, S. H.; Carreira, L. A.; Baughman, G. L.; Karickhoff, S. W.; Melton, C. M. J. Phys. Org. Chem. 1994, 7, 122.

(42) NIST Standard Reference Database 35, NIST/EPA Gas-Phase Infrared Database; National Institute of Standards and Technology: Gaithersburg, MD. 